\title{
Predation in Ground-Nesting Birds: an Experimental Study Using Natural Egg-Color Variation
}

\section{Prédation chez les oiseaux nichant au sol : étude expérimentale fondée sur la variation naturelle de la coloration des œufs}

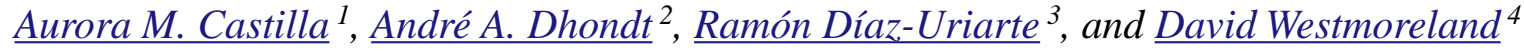

\begin{abstract}
We tested the hypothesis that cryptically colored eggs would suffer less predation than conspicuous eggs in the ground-nesting red-legged partridge, Alectoris rufa. We used A. rufa as a model species because it has a wide range of natural egg colors, the eggs are widely available from breeding farms, and nests are easily mimicked because they are scrapes containing no vegetation. The study was conducted in the spring of 2001 in forest and fallow fields of central Spain in Castilla La Mancha, Ciudad Real. We used 384 clutches of natural eggs that were white, white spotted, brown, or brown spotted. Within clutches, eggs were consistent in color and size; among clutches, color differences were distributed across habitats. Clutches were checked once after 2 wk of exposure. Cryptic coloration had a survival advantage that was dependent on the local suite of predators. Rodent predation was nonselective with respect to clutch color; however, avian predation was significantly higher for conspicuous clutches. In addition, there was an interaction of landscape and egg color for avian predation. In forest landscapes, the clutches with highest survival were brown spotted, whereas in fallow landscapes, brown and brown spotted clutches had higher survival than white and white potted clutches. Thus, both the predator suite and the landscape had significant effects on the value of cryptic egg coloration. Our study is relevant for conservationists and managers in charge of restocking programs in hunting areas. The release of other partridge species or their hybrids could result in hybridization with wild partridges, potentially leading to nonoptimal clutch pigmentation and reduced survival of the native species. We therefore recommend that local authorities, managers, and conservationists be cautious with the use of alien species and hybrids and release only autochthonous species of partridges within their natural ranges.
\end{abstract}

RÉSUMÉ. Nous avons testé l'hypothèse selon laquelle les œufs à coloration cryptique seraient moins sujets à la prédation que les œufs bien visibles chez la Perdrix rouge, Alectoris rufa. Nous avons choisi A. rufa comme espèce-cible parce que ses œufs présentent une grande variété de couleurs naturelles, qu'il est possible de se les procurer facilement dans les fermes d'élevage et que les nids sont faciles à imiter étant donné que ce sont de simples dépressions ne contenant aucune végétation. L'étude a été menée au printemps 2001 dans des forêts et des champs en jachère du centre de l'Espagne (Castilla La Mancha, Ciudad Real). Nous avons simulé 384 couvées constituées d'œufs de couleur naturelle qui étaient blancs, tachetés de blanc, bruns ou tachetés de brun. Dans une même couvée, la coloration et la taille des oufs étaient uniformes et les couvées des différentes couleurs ont été réparties dans les divers habitats. Les couvées ont été vérifiées une seule fois après deux semaines d'exposition. La coloration cryptique augmentait les probabilités de survie mais cet avantage variait selon la combinaison de prédateurs locaux. La prédation effectuée par les rongeurs n'était pas sélective par rapport à la couleur de la couvée; cependant, le taux de prédation associé aux oiseaux était significativement plus élevé dans le cas des couvée bien visibles. De plus, il y avait une interaction entre le paysage et la couleur des œufs dans le cas de la prédation aviaire. Dans les paysages

${ }^{1}$ Museo Nacional de Ciencias Naturales de Madrid, ${ }^{2}$ Laboratory of Ornithology, Cornell University, ${ }^{3}$ Bioinformatics Unit, Spanish National Cancer Center, ${ }^{4}$ U.S. Air Force Academy

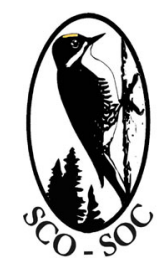

Sponsored by the Society of Canadian Ornithologists and Bird Studies Canada Parrainée par la Société des onnithologistes du Canada et Études d'oiseaux Canada

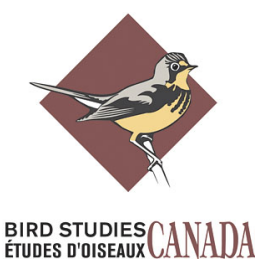


forestiers, les couvées dont le taux de survie était le plus élevé étaient constituées d'œufs tachetés de brun, alors que dans les champs en jachère, les couvées aux œufs bruns ou tachetés de brun présentaient un taux de survie plus élevé que celles aux œufs blancs ou tachetés de blanc. Ainsi, la combinaison de prédateurs et le paysage ont tous deux des effets significatifs sur la valeur de la coloration cryptique des œufs. Notre étude est pertinente pour les spécialistes en conservation et les gestionnaires qui s'occupent des programmes de rétablissement des stocks dans les secteurs ouverts à la chasse. Le lâcher d'autres espèces de perdrix ou de leurs hybrides pourraient amener une hybridation avec les perdrix sauvages, ce qui pourrait entraîner une pigmentation non optimale des œufs et réduire le taux de survie de l'espèce indigène. Nous recommandons donc que les autorités locales, les gestionnaires et les spécialistes en conservation utilisent avec prudence les espèces non indigènes et les hybrides et ne relâchent que des perdrix appartenant à des espèces indigènes dans leur aire de répartition naturelle.

Key Words: egg color variation; egg crypsis; landscape variation; natural selection; predation

\section{INTRODUCTION}

Nest predation is the main cause of reproductive failure for a wide range of bird species (Ricklefs 1969). Because eggs are eaten by predators and it is generally believed that egg color functions as crypsis to reduce nest predation (e.g., O'Connor 1985), the adaptive significance of egg color is usually taken for granted (Götmark 1992). In fact, since the time of Wallace (1889), predation pressure has been assumed to be the most important selective pressure on eggshell pigmentation. However, egg color may be subjected to other selection forces that influence egg physiology, e.g., thermoregulation and gas exchange, and protection from incident radiation (Montevecchi 1976a, Bertram and Berger 1981, Underwood and Sealy 2002). It can also be a sexually selected signal of female quality (Moreno and Osorno 2003, Moreno et al. 2005).

To be cryptic, animal coloration must to some degree resemble the visual texture of the background (Endler 1978, Merilaita et al. 1999). Although it seems obvious that cryptically colored eggs should reduce predation in ground-nesting birds, few studies have examined the adaptive significance of egg coloration, and tests of this hypothesis have largely failed to document such an effect. More studies have found no effect of egg color on predation risk than have found such an effect (Table 1). Of 14 experiments that were conducted between 1958 and 1997,9 (64\%) showed no effect of egg color on predation risk, 4 (29\%) found an effect, and one (7\%) showed an effect, but in an unexpected direction, i.e., the more spotted, putatively more cryptic eggs were taken more often.
It may be that egg color is irrelevant to survival, so that experiments have correctly failed to reject the null hypothesis. Alternatively, the failure to detect a coloration effect could be related to commonly used aspects of experimental design. By examining the available literature (Table 1), we observed that the studies in which eggs were painted show no effect of egg color on predation risk, whereas the reverse is true of studies that used naturally colored eggs (but see Montevecchi 1976b). These observations suggest that the painting of eggs may not be an appropriate experimental procedure.

Among studies that used naturally pigmented eggs, opposite findings, e.g., "positive" (Yahner and Mahan 1996) or "negative" (Jobin and Picman 1997), are difficult to resolve because the authors used different experimental designs such as the number of eggs per nest and type of habitat. In addition, some of the experiments were conducted using eggs of different size and color simultaneously. Because egg size influences egg predation (Montevecchi 1976b), the interpretation of the influence of color per se is obscure. There is a clear need for further experiments to test whether egg color influences egg predation in groundnesting birds.

Therefore, we examined the effect of egg color in a ground-nesting species, the red-legged partridge, Alectoris rufa. We used natural eggs of this species, taking advantage of the fact that partridges are farmraised, making it possible to obtain large samples of eggs that match those of natural populations in size and color (Castilla and Rodríguez 2002). In addition, experimental replicates of partridge nests 
Table 1. Results of studies examining the effect of egg pigmentation on nest predation.

\begin{tabular}{|c|c|c|c|c|c|c|c|}
\hline Author & Year & Species & Egg type $\dagger$ & $\begin{array}{l}\text { Pigment- } \\
\text { ation des- } \\
\text { ign } \$\end{array}$ & Egg color§ & Predator & Effect \\
\hline Kruyt & 1958 & Gull & $\mathrm{pt}$ & $\mathrm{sp}+\mathrm{u}$ & & Gull & No \\
\hline \multirow[t]{3}{*}{ Tinbergen } & 1962 & Gull & nat + pt & $\mathrm{sp}+\mathrm{u}$ & wh & Gull, corvid & Yes \\
\hline & & Gull & $\mathrm{pt}$ & $\mathrm{sp}+\mathrm{u}$ & & Gull, corvid & No \\
\hline & & Hen & $\mathrm{pt}$ & $\mathrm{br}+\mathrm{u}$ & & Gull, corvid & No \\
\hline \multirow[t]{2}{*}{ Davies } & $\begin{array}{l}\text { unpublis- } \\
\text { hed man- } \\
\text { uscript }\end{array}$ & - & $\operatorname{mimic}$ & $\mathrm{sp}$ & & Corvid & No \\
\hline & & - & mimic & $\mathrm{sp}$ & & Gull & Yes \\
\hline \multirow[t]{4}{*}{ Montevecchi } & $1976 \mathrm{a}$ & Hen & $\mathrm{pt}$ & $\mathrm{sp}+\mathrm{u}$ & wh, kh & Corvid & No \\
\hline & & Hen & $\mathrm{pt}$ & $\mathrm{sp}+\mathrm{u}$ & wh, bl & Corvid & No \\
\hline & & Gull hen & nat + pt & $\mathrm{sp}+\mathrm{u}$ & wh, kh & Corvid & No \\
\hline & & Quail & nat $+\mathrm{pt}$ & $\mathrm{sp}+\mathrm{u}$ & wh & Corvid & Yes \\
\hline \multirow[t]{2}{*}{ Montevecchi } & $1976 b$ & & $\mathrm{pt}$ & & & Covid & No \\
\hline & & & $\mathrm{pt}$ & & & Corvid & Yes \\
\hline Yanher and Manhan & 1996 & Quail hen & nat & $\mathrm{sp}+\mathrm{u}$ & br, wh & Corvid, mammal & Yes \\
\hline Jobin and Picman & 1997 & Hen & nat & $\mathrm{u}$ & br, wh & Corvid, mammal & No \\
\hline This study & 2007 & Partridge & nat $/ p l$ & $\mathrm{sp}+\mathrm{u}$ & br, wh & Bird, mammal & Yes \\
\hline
\end{tabular}

$\dagger$ mimic, human-made artifical replicas; nat, natural eggs; nat/pl, natural eggs filled with plaster; pt, painted eggs.

$\$$ sp, spotted secondary pigmentation; $\mathrm{u}$, uniform pigmentation.

$\S$ sp, spotted; bl, black; br, brown, kh, khaki; wh, white.

are easily constructed because they are scrapes that contain no vegetation.

We compared predation rates for clutches with four different pigmentation classes that are observed in nature. We assumed that the degree of crypsis of the clutches would increase ordinally as follows: pure white, which is the most conspicuous to the human eye; spotted white; uniform brown; and spotted brown. To examine the influences of habitat type and predator suite, we conducted the experiments in fallow fields and forested landscapes simultaneously. Both of these landscapes are used by $A$. rufa during its daily, seasonal, and reproductive activities (Castilla and Rodríguez 2002, Castilla and Martínez 2007). 
Because the risk of predation for white and pale eggs is high in common Mediterranean habitats of dark background (Castilla et al. 2002), human activity that increases the production of eggs differing in color from those of the original population should be prevented. Other partridge species that produce whitish eggs, e.g., Alectoris chukar, A. graeca, and $A$. barbara, are crossed with $A$. rufa to increase farm production. In Spain, nearly four million partridges are released every year for hunting or stocking, but these activities are conducted without any kind of regulatory oversight. Assuming that egg color is heritable (Wei et al. 1992, Francesch et al. 1997), it would be advisable for local authorities, managers, and conservationists to be cautious with the use of alien species and hybrids, and release only autochthonous species of partridge in their range.

\section{METHODS}

\section{Study area}

The study was conducted during May 2001 in Encomienda de Mudela, Castilla La Mancha, Ciudad Real, an area of central Spain used for hunting. The area was dominated by oak woodland composed of Quercus ilex, Juniperus oxycedrus, Olea europaea, Quercus coccifera, Rosmarinus officinalis, Lavandula stoechas, Rubus sp., and Thymus sp., mixed with cereals such as barley, wheat, and oats, fallow fields, and grasses. The substrate color was variable, but mainly brown, i.e., soil mixed with fresh and dry oak leaves. Cereal fields were cultivated with wheat, barley, and oats, which varied in height from 30 to $200 \mathrm{~cm}$. Fallow fields were large areas of soil, mainly without vegetation. The soil color was of various dark and pale tones of reddish-brown.

A variety of corvids occurred in the study area: Garrulus glandarius, Cyanopica cyanus, Corvus monedula, Corvus corax, and Corvus corone. Magpie, Pica pica, was not abundant due to trapping by humans. A variety of mammals also occurred in the area: domestic cats and dogs, Vulpes vulpes, Genetta genetta, Meles meles, Martes foina, Mustela nivalis, and several species of rodent.

\section{Nests}

Partridges do not build nests of vegetation, but lay their eggs in bare scrapes on the ground. We therefore mimicked nest sites by making small excavations in the substrate without adding materials such as leaves and feathers. Thus, we avoided biases associated with the use of artificial nests, which poorly mimic natural nests (Faaborg 2004, Moore and Robinson 2004, Villard and Pärt 2004).

In the study area and in northeastern Spain, i.e., Catalonia, partridges nest in a large variety of habitats that differ in the degree of overarching cover. Nests can be completely exposed from above or with little cover or can be located under dense and spiny vegetation, at the base of trees such as oaks, olives, and almonds, under rocks, within cereal fields that differ in vegetation height, in fallow fields, or in old abandoned houses.

To our knowledge, there has been no quantitative study of the nest characteristics of Alectoris rufa or its densities in different habitats in Spain. We thus decided to mimic the simplest scenario in this experiment. In the forest, we placed all nests adjacent to a tree, shrub, or herb, leaving the nests partially visible. In the fallow, all nests were placed on the ground with no cover from above. We maintained the same nest density and the same distance among nests in the four study areas.

\section{Eggs}

Eggs of A. rufa have traditionally been described as having a brownish-yellow background with dense brownish-red spots (Cramp and Simmons 1980). Today, however, a larger range of color variation is observed in different zones of Spain (Castilla and Rodríguez 2002). Unfortunately, there are no quantitative studies of egg color variation for $A$. rufa in different habitats over its geographic range, and thus there are no data on the frequency distribution of egg colors. In at least some areas, the historical increase in egg color variation could be the result of hybridization with commercially produced and released game species that produce paler eggs (Harrison 1975). Most A. rufa populations in Spain are crossed with other species such as $A$. graeca, $A$. 
chuckar, and A. barbara (Instituto de Investigación de Recursos Cinegéticos unpublished data), and hybrids probably produce eggs of paler color than do A. rufa.

We obtained eggs from two farms, Altube S. A. and Quintos de Mora, and used eggs of four color patterns that had been observed in natural nests at the study site: uniform white, whitish background with brownish-red spots, uniform brown, and brownish background with brownish-red spots, hereafter white, spotted white, brown, and spotted brown, respectively.

The eggs of $A$. rufa show significant size variation (Castilla 2001), and egg size is known to influence predation rates (Montevecchi 1976b). Thus, we used pairs of eggs of similar size, approximately 40 in length $\times 30 \mathrm{~mm}$ in width, to create clutches that were placed in the center of each nest scrape. The egg size criteria were consistent within and among clutches throughout the study.

Because birds primarily use visual cues to capture their prey, we attempted to distinguish between birds and other predators by obtaining imprints of teeth or beaks by drilling a hole in both sides of each egg and replacing the egg contents with clay (see Castilla 1995). Before the clay dried, we inserted a small wire through one of the holes in the egg. A nylon cord of $14 \mathrm{~kg}$ resistance was attached to the wire and to a metal stake that had been driven to ground level at the center of each nest scrape.

\section{Experimental design}

The study was conducted in fallow fields and nearby forested landscapes in which natural nests had been observed. The entire study site covered about 50 $\mathrm{km}^{2}$. We chose four zones of $1850 \mathrm{~m}$ in length $\times$ $150 \mathrm{~m}$ in width. Two fallow zones separated by 1 $\mathrm{km}$ occupied the centre of the study site. Forest zones were established on each side and were separated from the fallow zones by $3-4 \mathrm{~km}$.

Because predation rates are influenced by habitat, landscape, season, nest density, nest characteristics, and human visitation (Major and Kendal 1996), all clutch types were presented in each zone. Clutches were placed in all experimental plots during the same time period, and the number of observers and frequency of nest visitation was standardized.
Within each zone, we laid out six plots, each with 16 nest scrapes, for a total of 96 nest scrapes. Nests scrapes were placed in four parallel lines and were spaced in a systematic fashion, with $50 \mathrm{~m}$ between nests scrapes within each plot. The between-plot distance was $200 \mathrm{~m}$. We used a Latin square design to randomize egg color among rows and columns. The distance between rows and columns was $50 \mathrm{~m}$. In the forest, nests were placed near, but not under, vegetation. Locations were recorded using a Garmin-Emap GPS, and a numbered flag was placed $6 \mathrm{~m}$ away. We also recorded the type of vegetation, i.e., herb, shrub, tree, or none, and the vegetation height near each nest. Preliminary data showed very low predation rates of about $20 \%$ after $1 \mathrm{wk}$. Thus, a single clutch check was made after 2 wk.

\section{Predator recognition}

Nest predators such as birds and mammals were categorized by the marks left in the clay of the eggs. Some bill marks were clearly distinguishable from those of the incisors of mammals (Major and Kendal 1996). When eggs were completely broken or had unrecognizable marks, we assigned them the category of unknown. Clutches that were completely missing from scrapes were classified as disappeared.

\section{Statistical procedures}

A clutch was considered predated when one or both eggs was attacked. We calculated the effects of color and landscape, as well as of type and height of vegetation, on the predation probability using logistic regression with random effects. We incorporated random effects of plot, and of the interaction of row and column nested within plot (Diggle et al. 1994, Littell et al. 1996).

Generalized linear mixed models were fitted using the GLIMMIX macro for Statistical Analysis Software (SAS). Model selection was based both on the $F$ tests for the terms in the model, e.g., color, landscape, vegetation type, and vegetation height, and by comparisons of the deviance of competing nested models. We used $F$ tests based on the Wald statistics that are implemented in the SAS macro (Littell et al. 1996). All fitted models were checked using the diagnostics in Collett (1991). Model checking was carried out using R (R Development 
Core Team 2004). To compare predation rates between landscapes and among colors we carried out a posteriori comparisons on logit-transformed data using LSMEANS in SAS. The predation rates presented here are the back-transformed proportions as calculated in the analyses.

It was not our objective to examine the effect of vegetation on predation rates; however, because it is impossible to place all nests under identical conditions in nature, we examined possible effects of vegetation nest predation rates. The analyses were carried out using models that fitted color, vegetation type, and vegetation height.

To compare vegetation characteristics among zones in the forest, we used permutation tests. These were chi-square analyses of contingency tables in which the reference distribution used to test significance of the chi-square was obtained by randomly reallocating complete plots to landscapes, so that we always preserved the within-plot characteristics. All permutation tests were carried out using functions that we wrote and executed in $\mathrm{R}$.

\section{RESULTS}

Thirty-eight clutches were destroyed accidentally by agricultural machines or cattle; thirty-one of these were in fallow, whereas seven were in forest. These were excluded from the analyses, reducing the sample size to 346 clutches.

\section{Nest placement}

Egg color was randomly distributed among vegetation types in the forest habitats $\left(\chi^{2}=4.520\right.$, $\mathrm{df}=9, P=0.90)$ and vegetation height $\left(\chi^{2}=17.508\right.$, df $=15, P=0.29)$. Therefore, comparisons of predation rates on eggs differing in color were not biased by differences in vegetation near the nests. In the forest, we found no effect of vegetation height $(P>0.3)$ on predation rates, but there was a weak effect of vegetation type, e.g., tree, shrub, herb $\left(F_{2}\right.$, $\left.{ }_{97}=2.94, P=0.057\right)$. Predation rates tended to be higher among nests placed near trees $(0.42)$ and shrubs (0.39) than near herbs (0.16). The majority of nests $(72 \%)$ were located near trees; ideally, we would have liked to place all nests near trees, but the constraint of equal distances of $50 \mathrm{~m}$ between nests prevented this.

\section{Influence of egg color on nest predation}

We analyzed the effects of egg color on predation first, without regard to predator identity, and then performed separate analyses for bird predation. The logistic regression included landscape and color as main effects, the interaction effect of landscape and color, and plot. Rows and columns were nested within plots as random effects.

For all predators combined, the final model included the main effects of landscape $\left(F_{1,179}=15.17, P<\right.$ $0.0001)$ and color $\left(F_{3,179}=2.80, \dot{P}=0.04\right)$, but not the landscape-by-color interaction $\left(F_{3,176}=1.59, P\right.$ $=0.19)$. There were no significant differences in predation rates between white and spotted white eggs or between brown and spotted brown eggs, but the predation rate on white eggs was about twice that on brown eggs (Table 2).

Considering predation by birds only, the final model included the main effects of color $\left(F_{3,176}=9.41, P\right.$ $=0.0001)$ and landscape $\left(F_{1,176}=4.98, P=0.027\right)$, in addition to the color-by-landscape interaction $\left(F_{3}\right.$, $176=3.37, P=0.02)$. Predation in general was lower in the fallow than in the forest. In forest habitats, predation was significantly lower on clutches containing spotted brown eggs than on clutches of other colors (all comparisons, $\mathrm{P}<0.001$ ). In the fallow, predation rates were significantly higher on spotted white and white eggs than on brown and spotted brown eggs (all comparisons, $P<0.03$; Fig. $1)$.

\section{Nest predators}

Considering all 346 clutches, a predation event, i. e., one or both eggs taken, occurred at $94(27.2 \%)$ nest scrapes (Table 3). It was possible to identify the predator group in 63\% of these cases (Table 4). Clutch predation was assigned to birds in $35 \%$ of clutches and to mammals in $28 \%$. In the fallow, birds were the most important predators at $41 \%$, whereas unknown predators caused $32 \%$ of clutch losses, and attacks by rodents were negligible at $5 \%$. In the forest, birds accounted for $33 \%$ of clutch losses and rodents for $19 \%$. Intererestingly, rodents were equally likely to take eggs of any color (Table 4). 
Table 2. Predation rates of all predators combined by landscape across all egg colors and by egg color across all landscapes.

\begin{tabular}{lrccr}
\hline \hline Variable & & Predation rate & Group ${ }^{\dagger}$ & $95 \%$ confidence li \\
\hline Landscape & & & & \\
& Forest & 0.354 & $\mathrm{a}$ & $0.240,0.489$ \\
& Fallow & 0.092 & $\mathrm{~b}$ & $0.050,0.165$ \\
Egg color & & & & \\
& White & 0.258 & $\mathrm{c}$ & $0.165,0.380$ \\
& Spotted white & 0.237 & $\mathrm{c}$ & $0.150,0.354$ \\
& Brown & 0.128 & $\mathrm{~d}$ & $0.072,0.216$ \\
& Spotted brown & 0.163 & $\mathrm{~cd}$ & $0.096,0.265$
\end{tabular}

Note: Means were compared a posteriori using the LSMEANS function in Statistical Analysis Software and the logit-transformed proportions.

$\dagger$ Groups with the same letter do not differ significantly at $P=0.05$.

\section{DISCUSSION}

Our results are consistent with those of another study conducted during the same year in Catalonia, northeastern Spain (Castilla et al. 2002). Castilla et al. (2002) used identical methods and placed 384 nests in four pine forests that were burned during a wildfire. Much of the substrate was still black, and differences were expected in the survival of eggs of differing color. Castilla et al. (2002) recorded bird predation in $52 \%$ of nests with white eggs, whereas the rate of predation on brown spotted eggs was $27 \%$. The tendency for white or pale eggs to have higher predation rates than cryptic eggs has been reported in many field experiments in which naturally colored eggs were used (e.g., Tinbergen et al. 1962, Montevecchi 1976a, Westmoreland and Best 1986, Yahner and Mahan 1996, Jobin and Picman 1997, Weidinger 2001).

Interestingly, the survival advantage of brown spotted eggs of Alectoris rufa is accompanied by a significantly greater hardness, requiring $30 \mathrm{~N}$ of force to break through the shell compared to $24 \mathrm{~N}$ for white eggs (Castilla et al. 2006). If predators prefer paler eggs and paler eggs are generally thinner than darker eggs, light egg pigmentation could adaptively focus the attention of predators on the weakest eggs within a clutch.

Our results also indicate that the value of coloration is dependent on the suite of predators. Rodents were nonselective and took eggs of all colors equally. A similar tendency was found for mammal predators in a burned pine forest of Catalonia, Spain (Castilla et al.2002). In contrast, birds were strongly selective of certain egg patterns. Thus, analyses that fail to discriminate among predators can fail to note the importance of egg coloration. This might explain the negative results of studies that found no significant advantage of cryptic egg coloration (e. g., Jobin and Picman 1997).

For avian predators, there was an interaction between landscape and egg color. In the forest landscape, brown spotted eggs had higher survival than eggs of all other colors. In the fallow landscape with brown soil, brown and brown spotted eggs had 
Fig. 1. Predation rates by birds in different landscapes as predicted by logistic regression. Different lowercase letters indicate significant differences among groups (LSMEANS function in Statistical Analysis Software, $\mathrm{p}<0.05$ ). Bars, standard error.

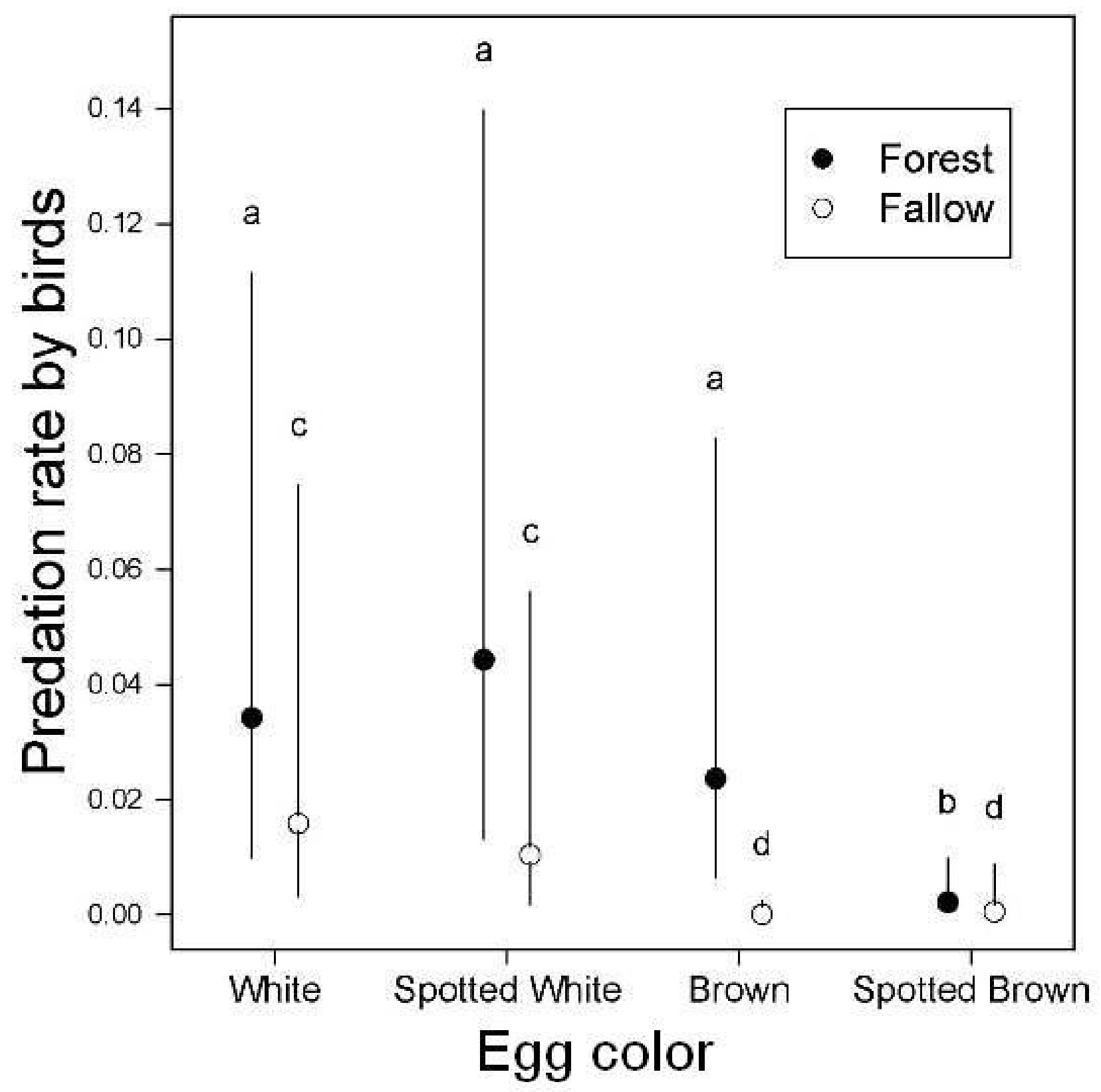


Table 3. Numbers of clutches placed in 24 plots in four zones and predated after 2 wk.

\begin{tabular}{|c|c|c|c|}
\hline Zone & Plot & Number of clutches & Number of clutches predated \\
\hline \multirow[t]{7}{*}{1 , forest } & 1 & 16 & 4 \\
\hline & 2 & 16 & 5 \\
\hline & 3 & 16 & 3 \\
\hline & 4 & 16 & 7 \\
\hline & 5 & 16 & 8 \\
\hline & 6 & 16 & 9 \\
\hline & Total & 96 & 36 \\
\hline \multirow[t]{7}{*}{2 , forest } & 7 & 16 & 7 \\
\hline & 8 & 16 & 8 \\
\hline & 9 & 16 & 2 \\
\hline & 10 & 16 & 8 \\
\hline & 11 & 9 & 1 \\
\hline & 12 & 16 & 10 \\
\hline & Total & 89 & 36 \\
\hline \multirow[t]{7}{*}{3 , fallow } & 13 & 13 & \\
\hline & 14 & 16 & 4 \\
\hline & 15 & 11 & 1 \\
\hline & 16 & 14 & \\
\hline & 17 & 15 & 1 \\
\hline & 18 & 16 & 4 \\
\hline & Total & 85 & 10 \\
\hline \multirow[t]{7}{*}{4 , fallow } & 19 & 11 & 1 \\
\hline & 20 & 16 & 3 \\
\hline & 21 & 15 & 2 \\
\hline & 22 & 3 & \\
\hline & 23 & 16 & 6 \\
\hline & 24 & 15 & \\
\hline & Total & 76 & 12 \\
\hline
\end{tabular}

Note: Clutches destroyed by agricultural machinery are not included. 
Table 4. Clutch losses attributed to different types of predators.

\begin{tabular}{|c|c|c|c|c|c|c|c|}
\hline \multirow[t]{2}{*}{ Predator } & \multirow{2}{*}{$\begin{array}{l}\text { Total no. } \\
\text { predators }\end{array}$} & \multicolumn{4}{|c|}{ Egg color pattern } & \multicolumn{2}{|c|}{ Landscape } \\
\hline & & $\begin{array}{l}\text { Uniform w- } \\
\text { hite }\end{array}$ & $\begin{array}{l}\text { Uniform br } \\
\text { own }\end{array}$ & - Spotted w- & Spotted brown & Forest & Fallow \\
\hline Birds & 33 & 12 & 6 & 12 & 3 & 24 & 9 \\
\hline Rodents & 15 & 4 & 3 & 1 & 7 & 14 & 1 \\
\hline Mammals & 11 & 3 & 5 & 2 & 1 & 9 & 2 \\
\hline Indeterminate, eggs present & 20 & 4 & 3 & 7 & 6 & 17 & 3 \\
\hline Indeterminate, eggs removed & 15 & 5 & 2 & 5 & 3 & 8 & 7 \\
\hline \multirow[t]{2}{*}{ Total no. predated clutches } & 94 & 28 & 19 & 27 & 20 & 72 & 22 \\
\hline & 94 & \multicolumn{4}{|c|}{94} & \multicolumn{2}{|c|}{94} \\
\hline
\end{tabular}

higher survival than eggs of other colors, indicating that the background color of eggs was the key factor in survival. Our samples sizes for this effect were small and the $P$ values were not highly significant, so these trends could be attributed to sampling error. However, the findings may also be explained by differences in the visual complexity of the landscapes. The presence of nearby and overarching vegetation in the forest habitat may have created a patchy pattern of sun and shade on the substrate. Thus, spotted brown eggs would match not only the substrate color, but also the complex pattern of light and dark created by vegetation intercepting the sunlight. In contrast, fallow fields had a less complex visual pattern, so the background color of eggs was the primary determinant of survival and spotting did not confer a survival benefit.

Some authors have already suggested that eggshell polymorphism may have resulted from adaptation to the choice of breeding site and variation in the color of background substrates (Weidinger 2001, Blanco and Bertellotti 2002). Others have suggested that egg color variation in ground nesting birds may have evolved from differences in predator suites (Blanco and Bertelloti 2002). However, egg color variation may be subjected to other selection forces that may differ in intensity depending on the habitat or even among years within a given habitat.

The genetic or physiological causes of eggshell polymorphism in A. rufa are unknown. However, because there seems to have been an increase in eggshell polymorphism in the last $25 \mathrm{yr}$, mutation and selection are unlikely explanations. Rather, it seems likely that natural populations of this species have hybridized with other partridge species that are commercially produced and released for hunting. If so, the commercial practice has introduced egg color alleles that probably reduce the fecundity of the native partridge population. Although it is possible that some egg color variants are adaptive in some parts of the species' range, e.g., partridges in calcareous zones that have whitish substrates may benefit from light-colored eggs, it is more likely that the introduced alleles are generally maladaptive. We thus suggest caution with the release of nonnative species within the range of native $A$. rufa. 
Responses to this article can be read online at: http://www.ace-eco.org/vol2/iss1/art2/responses/

\section{Acknowledgments:}

We thank Enric Pastor (Forestal Silvicat S.L.), Jose $M^{a}$ Figueras (Escuela de Capacitación Agraria del Solsonés) and Esther Pérez for great help and assistance in the field; Carmen López (Spanish National Parks Service), who prepared and measured the eggs; and Carlos Rodríguez, who facilitated permissions and assisted during the study. We thank the gamekeepers of Encomienda de Mudela (Julián, Esteban, and Ambrosio). Jesús Herranz identified predator marks on the eggs. Dirk Bauwens and Juan Moreno provided us with literature, and D. Bauwens, Dr. Marc-André Villard, and Dr. Bertellotti commented on the manuscript. We very much thank the farms Agrocinegética Altube S.A. and Quintos de Mora (Junta de Comunidades de Castilla La Mancha, Toledo)for providing a large number of partridge eggs. This paper is a contribution from the Biological Station of Sanaüja, the National Science Museum of Madrid (CSIC). This work was conducted on a contract "Ramón and Cajal" to AMC from the Spanish National Science Foundation (CSIC, Ministerio de Educación y Ciencia) and supported by the Organismo Autónomo de Parques Nacionales (Ministerio de Medio Ambiente).

\section{LITERATURE CITED}

Bertram, B. C. R., and F.A. Burger. 1981. Are ostrich Struthio camelus eggs the wrong colour? Ibis 123:207-210.

Blanco, G., and M. Bertellotti. 2002. Differential predation by mammals and birds: implications for egg-colour polymorphism in a nomadic breeding seabird. Biological Journal of the Linnean Society 75:137-146.

Castilla, A. M. 1995. Intensive predation of artificial Audouin's gull nests by the yellow-legged gull in the Columbretes Islands, Spain. Colonial Waterbirds 18:226-230.

Castilla, A. M. 2001. Huevos de perdiz roja (Alectoris rufa) de granjas cinegéticas. Trofeo-Caza y Conservación 372:34-38.
Castilla, A. M., A. Herrel, G. Díaz, and A. Francesch. 2006. Importancia de la cáscara del huevo en perdiz roja (Alectoris rufa) y codorniz (Coturnix japonica). Jara y Sedal 54:78-82

Castilla,A. M., and J. Martínez. 2007. Adaptación de las perdices (Alectoris rufa) al campo: la forma de recuperar poblaciones y disfrutar de la caza. Repofot, Madrid, Spain, in press.

Castilla, A. M., E. Pérez, and E. Pastor. 2002. Depredación de nidos de perdiz roja (Alectoris rufa) en los bosques quemados de Riner y Pinós (Solsonés, Lleida, Catalonia, España). Unpublished report to Centro Tecnológico Forestal de Cataluña, Solsona, Spain.

Castilla, A. M., and C. Rodríguez. 2002. Influencia de la depredación y de otros factores sobre la pérdida de nidos de perdiz roja (Alectoris rufa) en la Encomienda de Mudela, Castilla La Mancha (Ciudad Real). Serie Técnica. Organismo Autónomo Parques Nacionales, Ministerio de Medio Ambiente, Madrid, Spain.

Collett, D. 1991. Modelling binary data. Chapman and Hall, London, UK.

Cramp, S., and K. E. L. Simmons. 1980. Alectoris rufa, red-legged partridge. Pages 463-469 in S. Cramp and K. E. L. Simmons, editors. Handbook of the birds of Europe, the Middle East and North Africa: The birds of the western paleartic. Volume 2. Oxford University Press, Oxford, UK.

Diggle, P. J., K. Y. Liang, and S. L. Zeger. 1994. Analysis of longitudinal data. Oxford University Press, New York, New York, USA.

Endler, J. A. 1978. A predator's view of animal color patterns. Evolutionary Biology 11:319-364.

Faaborg, J. 2004. Truly artificial nest studies. Conservation Biology 18:369-370.

Francesch, A., J. Estany, L. Alfonso, and M. Iglesias. 1997. Genetic parameters for egg number, egg weight, and eggshell color in three Catalan poultry breeds. Poultry Science 76:1627-1631.

Götmark, F. 1992. Blue eggs do not reduce nest predation in the song thrush, Turdus philomelos. Behavioral Ecology and Sociobiology 30:245-252. 
Harrison, C., editor. 1975. A field guide to the nests, eggs and nestlings of European birds, with North Africa and the Middle East. Collins, London, UK.

Jobin, B., and J. Picman. 1997. The effect of egg coloration on predation of artificial ground nests. The Canadian Field-Naturalist 111:591-594.

Kruyt, J. P. 1958. Speckling of the herring gull egg in relation to brooding behavior. Archives Neerlandaises de Zoologie 12:565-567.

Littell, R. C., G. A. Milliken, W. W. Stroup, and R. D. Wolfinger. 1996. SAS system for mixed models. SAS Institute, Cary, North Carolina, USA.

Major, R. E., and C. E. Kendal 1996. The contribution of artificial nest experiments to understanding avian reproductive success: a review of methods and conclusions. Ibis 138:298-307.

Merilaita, S., J. Tuomi, and V. Jormalainen. 1999. Optimization of cryptic coloration in heterogeneous habitats. Biological Journal of the Linnean Society 67:151-161.

Montevecchi, W. A. 1976a. Field experiments on the adaptive significance of avian eggshell pigmentation. Behaviour 58:26-39.

Montevecchi, W. A. 1976b. Egg size and the egg predatory behaviour of crows. Behaviour 57:307-320.

Moore, R. P., and W. D. Robinson. 2004. Artificial bird nests, external validity, and bias in ecological field studies. Ecology 85:1562-1567.

Moreno, J., J. Morales, E. Lobato, S. Merino, G. Tomás, and J. Martínez-de la Puente. 2005. Evidence for the signaling function of egg color in the pied flycatcher Ficedula hypoleuca. Behavioral Ecology 16:931-937.

Moreno, J., and J. L. Osorno. 2003. Avian egg colour and sexual selection: does eggshell pigmentation reflect female condition and genetic quality? Ecology Letters 6:803-806.

O'Connor, R. J. 1985. Eggs. Pages 173-176 in B. Campbell and E. Lack, editors. A dictionary of birds. $\mathrm{T}$ and $\mathrm{AD}$ Poyser, Calton, UK.
R Development Core Team. 2004. R: A language and environment for statistical computing. $\mathrm{R}$ Foundation for Statistical Computing, Vienna, Austria. URL: http://www.R-project.org.

Ricklefs, R. E. 1969. An analysis of nesting mortality in birds. Smithsonian Contributions to Zoology 9:1-48.

Tinbergen, N., G. J. Broekhuysen, F. Feekes, J. C. W. Houghton, H. Kruuk, and E. Szulc. 1962. Egg shell removal by the black-headed gull, Larus ridibundus L.; a behaviour component of camouflage. Behaviour 19:74-117.

Underwood, T. J., and S. G. Sealy. 2002. Adaptive significance of egg coloration. Pages 280-298 in D. C. Deeming, editor. Avian incubation, behaviour, environment and evolution. Oxford University Press, Oxford, UK.

Villard, M. A., and T. Pärt. 2004. Don't put all your eggs in real nests: a sequel to Faaborg. Conservation Biology 18:371-372.

Wallace, A. R. 1889. Darwinism. MacMillan, London, UK.

Wei, R., J. J. Bitgood, and M. R. Dentine. 1992. Inheritance of tinted eggshell colors in white-shell stocks. Poultry Science 71:406-418.

Weidinger, K. 2001. Does egg colour affect predation rate on open passerine nests? Behavioral Ecology and Sociobiology 49:456-464.

Westmoreland, D., and L. B. Best. 1986. Incubation continuity and the advantage of cryptic egg coloration to mourning doves. Wilson Bulletin 98:297-300.

Yahner, R. H., and C. G. Mahan. 1996. Effects of egg type on depredation of artificial ground nests. Wilson Bulletin 108:129-136. 